\title{
The interdisciplinarity in drug discovery
}

\begin{abstract}
The discovery of new drugs has singular importance for the social development of humanity and for the economic health of the pharmaceutical industry, being the main investor in research of the sector, and thus, responsible for most of the innovations in medicines. The science, which by genesis, has the discovery of new drugs as the main challenge is Medicinal Chemistry. This is currently supported by Synthetic Organic Chemistry, Computational Chemistry and Pharmacology. The difficulty of the drug discovery process varies according to the degree of knowledge about the target disease and its complexity. However, regardless of the level of difficulty, the success of the process depends on the cross-connection between various areas of knowledge, to overcome its disciplinary limits and generate active interdisciplinarity, so that specific knowledge has been produced in a particular way to resolve the problem.
\end{abstract}

Keywords: drug discovery, interdisciplinarity, medicinal chemistry, research and development
Volume 7 Issue 2 - 2018

\author{
Cleônia Roberta Melo Araújo,' Victória \\ Laysna dos Anjos Santos, ${ }^{2}$ Délis Galvão \\ Guimarães, ${ }^{2}$ Arlan de Assis Gonsalves ${ }^{3}$ \\ 'Collegiate of Sciences of Health and Biology, Federal University \\ of the São Francisco Valley, Brazil \\ ${ }^{2}$ Collegiate of Natural Resources of the Semi-Arid, Federal \\ University of the São Francisco Valley, Brazil \\ ${ }^{3}$ Collegiate of Materials Science, Federal University of the São \\ Francisco Valley, Brazil
}

\begin{abstract}
Correspondence: Cleônia Roberta Melo Araújo, Collegiate of Sciences of Health and Biology, Federal University of the São Francisco Valley, Avenue José de Sá Maniçoba, Petrolina Pernambuco, Brazil, Tel (87) 210I-6268, Email cleonia.araujo@univasf.edu.br
\end{abstract}

Received: January 30, 2018 | Published: April 24, 2018
Abbreviations: PI, pharmaceutical industry; R\&D, research and development; IUPAC, international union of pure and applied chemistry; NCE, new chemical entities; FDA, food and drug administration

\section{Introduction}

A disease it was treated with traditional medicines until the XVIII century and the efficacy of the remedies was attributed to the empiricism of popular culture. The development of new drugs as we know today was only possible because of the scientific advances of the XX century. Emphasizing the advances of chemistry, which has acquired maturity to apply its principles and methods to problems outside of chemistry, and the advances in pharmacology, which has become a well-defined science. ${ }^{1}$

The development of a new drug is laborious, time-consuming and demands high investments. It is estimated that an average of US \$802 million is needed for a new drug to be available for commercialization. ${ }^{2}$ This is an activity concentrated in the Pharmaceutical Industry (PI), main responsible for the innovations in sector. Academic researches aimed at the development of new drugs are held worldwide, and it produces knowledge that ends up being availed in the Research and Development (R\&D) sector of the PI.

The PI's innovations have specific and differentiated characteristics compared to other productive sectors, considering that $\mathrm{R} \& \mathrm{D}$ has a significant importance in the profitability of the sector and, in fact, innovative medicines bring new markets and extraordinary profits, ${ }^{3}$ known "blockbusters", drugs with annual revenues of more than US \$ 1 billion. There are 4 technological stages of the PI: Stage 1-Research and Development (R\&D); Stage 2-Production of pharmaceutical products; Stage 3-Production of pharmaceutical specialties; and Stage 4-Marketing and commercialization of pharmaceutical specialties. ${ }^{4}$

The discovery of new drugs is in the Technological Stage 1, where rational drug planning is based on the modern concepts of $R \& D$ of the
Medicinal Chemistry, science of interdisciplinary nature, defined by the International Union of Pure and Applied Chemistry (IUPAC), as:

Medicinal chemistry is a chemistry-based discipline, also involving aspects of biological, medical and pharmaceutical sciences. It is concerned with the invention, discovery, design, identification and preparation of biologically active compounds, the study of their metabolism, the interpretation of their mode of action at the molecular level and the construction of structure-activity relationships. ${ }^{5}$

\section{Discovery of new drugs}

There are several examples of drugs that have been discovered by serendipity, discovery by random when looking for something different, emphasizing the development of the antibiotics with the serendipity of Alexander Fleming ${ }^{6}$ and the discovery of chlordiazepoxide in 1954 by Leo Henryk Sternbach, ${ }^{7}$ which lead to the anxiolytics. However, the Medicinal Chemistry currently employs mainly the following strategies for the discovery of new drugs: discovery of a New Chemical Entities (NCE), in general innovative drugs; the molecular modification of existing drugs, known as "metoo"; and from biotechnological products. ${ }^{8}$

The search for a new drug begins a careful analysis is performed to determine the pathology. The social and economic aspects also are considered at this stage, as the costs in the R\&D of Medicinal Chemistry are high and the PI needs an adequate economic return to offset the financial investment as well as increase investments for new research. ${ }^{9}$

Research aimed at discovery a NCE are complex and in requires time and financial investments, and search for new chemical structures with potential pharmacotherapeutic use, either for already validated macromolecular targets or for new biological targets. The difficulty of R\&D projects to obtain candidates for drugs depends on the prior knowledge of the pathology and its complexity. Simplifying, there are the following scenarios: the biological target and the ligand are 
unknown; the biological target or the ligand is known; or the biological target and ligand are known, this being the most favorable situation. ${ }^{8}$

Considering the previously described, the drug discovery may occur based on known ligand, and its will be a design for generating a new series of molecules with similar chemical and biological properties. The drug discovery also may be based on the structure of the macromolecular target, for that, previously the macromolecular target must need been discovered, identified and validated. In this case is necessary the joint application of techniques of molecular biology, bioinformatics, biochemistry, pharmacology, genetic manipulation, nuclear magnetic resonance, crystallography and others are involved in this process. ${ }^{10}$

After determining the three-dimensional structure of the macromolecular target, the search for possible ligands can be done computationally, with the application of the concepts of database mining and of molecular docking program. ${ }^{11}$ This method is applied to virtual collections of compounds in an automated way, a mass virtual test. ${ }^{12}$ In this context, the chemoinformatics, an interdisciplinary area that uses in an integrated way computational resources, information technology and chemical information,,$^{13}$ has consolidated and its usefulness and impact to the medicinal chemistry tends to increase in the coming decades. Given the high expansion of databases with chemical information and biological properties relevant, and its exploitation and transformation of informations in the generated knowledges is essential for the discovery of new compounds with desired properties. ${ }^{13}$

The potential ligands delineated in the computational studies go to the in vitro screening, these tests are also important to screening of collections of molecules of natural origin or of combinatorial organic synthesis products. ${ }^{14}$ Considering the large number of virtual and real molecules, before the in vitro assays, the compounds are subjected to filters that consider the pharmacophoric groups already known, ${ }^{15}$ pharmacokinetic parameters, as the rule of the five of Lipinski's, ${ }^{4,16}$ and the synthetic viability, in the case of virtual molecules. The result obtained from the in vitro assays make possible the establishment of structure-activity relations, although this is a complex process due to the large number of information. ${ }^{17}$

The lead compound is reached from the most promising molecules identified in the previous step. Thereafter, series of congeners of the lead compound are prepared and will follow to the pharmacokinetics' and the pharmacodynamics' assays in vivo, and some molecules progress with preclinical and clinical studies. In 2107, Food and Drug Administration (FDA) approved 46 new drugs, of which 34 were NCE and 17 being potential to be "blockbusters". ${ }^{18}$

The modification of the chemical structure of a known drug to generate a new drug is a strategy called "me too". This process is simpler than the discovery of drug from ligands or macromolecular target, however several steps are need, such as: in vitro and in vivo assays' and preclinical and clinical studies'. Vardenafil is an example of "me-too" drug that was planned from sildenafil. ${ }^{17}$

After the genomic era, biopharmaceuticals have attracted the scientific community and investors. The genomic driven drug discovery and changing biological paradigm has resulted in significant changes in the biopharmaceutical industry, ceasing to be an academic discovery research to joint public-private discovery research strongly supported by information-based languages and technologies. ${ }^{19}$

The biopharmaceuticals refers to pharmaceuticals produced in biotechnological processes using molecular biology methods. ${ }^{20}$ Examples of biopharmaceuticals are antibiotics, cytokines, enzymes, blood factors, thromboembolytic agents activating plasminogen tissues, hormones, hematopoietic growth factors, interferons, vaccines and monoclonal antibodies. ${ }^{21,22}$ Due to such economic and strategic importance, biopharmaceuticals are among the pharmaceutical "blockbusters" resulting in $\$ 228$ billion in global sales in 2016..$^{22,23}$

The development of biopharmaceuticals has different stages, that the R\&D of Medicinal Chemistry is not adapted, because its expertise lies in the discovery of small molecules. Despite being a more complex process, several efforts are underway for the discovery of biopharmaceuticals, so much so that in 2017 the FDA approved 11 biopharmaceuticals. ${ }^{20}$ The development of biopharmaceuticals has social, economic and industrial relevance in the strategy for the development of new and promising approaches in the treatment of more complex, chronic and unusual diseases. ${ }^{21,24}$

Thus it can be said that currently the rational discovery of drugs is supported an essential triad to Medicinal Chemistry. This encompasses applied the synthetic organic chemistry, which deserves special designation, since it employs classical methods, low cost and high reproducibility at different scales, which may be called the Price's Principle (in reference to Barry Price when the invention of ranitidine). ${ }^{8}$ The computational chemistry, in particular the molecular modeling, for the agility of introducing three-dimensional structural factors of both micro and macromolecules, allowing simulations through models and the molecular recognition process. And the pharmacology by the numerous protocols of bioassays that allows to obtain quantitative results on the biological answers of the different designed derivatives in a series of congeners (Figure 1).

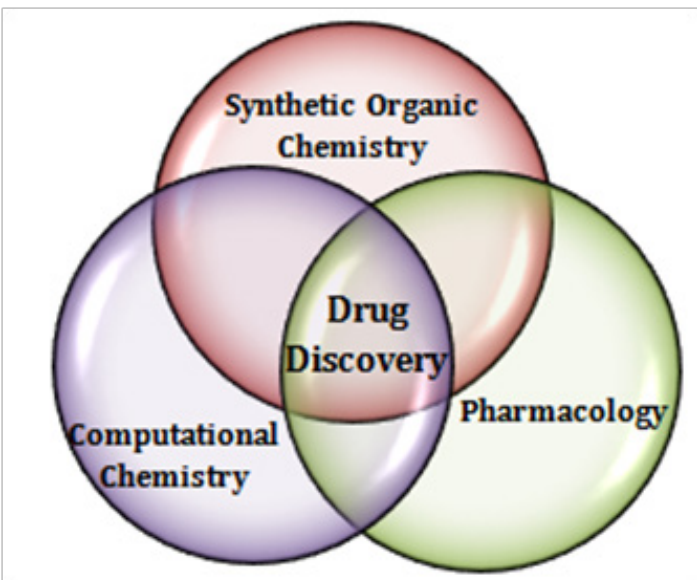

Figure I Simplified graphic illustration of interdisciplinarity in the discovery of drugs.

\section{Final considerations}

The scientific complexity of the discovery of new drugs, and the socioeconomic aspects of this process, makes it, in its genesis and in practice, an interdisciplinarity activity. Where there is a crossroads of disciplinary knowledge in the scientific field, and an organized effort 
of coordination, cooperation and communication that seek to resolve a social demand employing the integrated scientific knowledge. This vision of the whole process of drug discovery corroborates with the position that complex problems should be analyzed and consequently resolved without being restricted the knowledges and compartmentalized in curricular disciplines.

\section{Acknowledgements}

None.

\section{Conflict of interest}

The author declares that there are no conflicts of interest.

\section{References}

1. Drews J. Drug Discovery: A Historical Perspective. Science. 2000;287(5460):1960-1964.

2. DiMasi JA, Hansen RW, Grabowski HG. The price of innovation: new estimates of drug development costs. J Health Econ. 2003;22(2):151-185.

3. Vieira VMM, Ohayon P. Inovação em fármacos e medicamentos: estadoda-arte no Brasil e políticas de P\&D. Revista Economia \& Gestão. 2006;6(13):1-23.

4. Santos VLA, Gonsalves AA, Araújo CRM. Abordagem Didática para o Desenvolvimento de Moléculas Bioativas: Regra dos Cinco de Lipinski e Preparação de Heterociclo 1,3,4-Oxadiazol em Forno de Micro-Ondas Doméstico. Química Nova. 2018;41(1):1-6.

5. Wermuth CG, Ganellin CR, Lindberg P, et al. Glossary of Terms Used in Medicinal Chemistry. Pure \& Appl Chem. 1998;70(5):1129-1143.

6. Tan SY, Tatsumura Y. Alexander Fleming (1881-1955): Discoverer of penicillin. Singapore Med J. 2015;56(7):366-367.

7. López-Munoz F, Álamoa C, García-García P. The discovery of chlordiazepoxide and the clinical introduction of benzodiazepines: Half a century of anxiolytic drugs. J Anxiety Disord. 2011;25(4):554-562.

8. Fraga CAM, Lima LM, Barreiro EJ. O Paradigma Atual da Química Medicinal: Descoberta Racional do Composto-Protótipo. In: Montanari CA, editor., Química Medicinal Métodos e Fundamentos em Planejamento de Fármacos. São Paulo, Brazil: Editora da Universidade de São Paulo; 2011:47-65.

9. Pieroni JP, Capanema LXL, Reis C, et al. Terceirização da P\&D de medicamentos: panorama do setor de testes pré-clínicos no Brasil. BNDES Setorial. 2009;29:131-158
10. Hardy LW, Malikayil A. The impact of structure-guided drug design on clinical agents. Curr Drug Discov. 2003;15-20.

11. Kitchen DB, Decornez H, Furr JR, et al. Docking and scoring in virtual screening for drug discovery: methods and applications. Nat Rev Drug Discov. 2004;3(11):935-949.

12. Lengauer $\mathrm{T}$, Lemmen $\mathrm{C}$, Rarey $\mathrm{M}$, et al. Novel technologies for virtual screening. Drug Discovery Today. 2004;9(1):27-34.

13. Andrade $\mathrm{CH}, \mathrm{K} \ddot{u}$ mmerle $\mathrm{AE}$, Guido RVC. Perspectivas da Química Medicinal para o Século XXI: Desafios e Oportunidades. Quim Nova. $2018 ; 1-8$.

14. Leitão A, Montanari CA, Donnici CL. Sobre o Uso de Métodos Quimiométricos em Química Combinatória. Química Nova. 2000;23(2):178-184.

15. Langer T, Wolber G. Pharmacophore definition and 3D searches. Drug Discov Today Technol. 2004;1(3):203-207.

16. Lipinski CA. Lead-and drug-like compounds: the rule-of-five revolution. Drug Discov Today Technol. 2004;1(4):337-341.

17. Leitão A, Montanari MLC, Montanari CA. Desenvolvimento de Fármacos. In: Montanari CA, editor. Química Medicinal Métodos e Fundamentos em Planejamento de Fármacos. São Paulo, Brazil: Editora da Universidade de São Paulo; 2011;67-90.

18. Kesik-Brodacka M. Progress in biopharmaceutical development. Biotechnology and applied biochemistry. 2017.

19. Allarakhia M, Wensley A. Systems biology: A disruptive biopharmaceutical research paradigm. Technological Forecasting and Social Change. 2007;74(9):1643-1660.

20. Mullard A. 2017 FDA drug approvals. Nature Reviews Drug Discovery. 2017.

21. Almeida H, Amaral MH, Lobão P. Drugs obtained by biotechnology processing. Brazilian Journal of Pharmaceutical Sciences. 2011;47(2):199207.

22. Moorkens E, Meuwissen N, Huys I, et al. The market of biopharmaceutical medicines: A snapshot of a diverse industrial landscape. Front Pharmacol. 2017;8:314.

23. Albrecht I, Rhoden SA, Pamphile JA. Indústria biofarmacêutica e seu processo produtivo. Evidência-Ciência e Biotecnologia. 2015;15(1):57-68.

24. Sousa BCZG, Souza JN. Biofármacos: da pesquisa ao mercado: uma revisão da literatura. Saúde e Ciência em Ação. 2016;1(1):105-118. 